\title{
WhatsApp Mobile Tool in Second Language Learning: Opportunities, Potentials and Challenges in Higher Education Settings in Tanzania
}

\author{
Job W. Mwakapina \\ Department of Language Studies, College of Social Sciences and Humanities \\ Sokoine University of Agriculture, Box 3038, Morogoro, Tanzania \\ Tel: 2557-5577-4387Ｅ-mail: jvdwilson@yahoo.com

\begin{abstract}
Abdulkarim S. Mhandeni
Department of Language Studies, College of Social Sciences and Humanities

Sokoine University of Agriculture, Morogoro, Tanzania
\end{abstract}

Onesmo S. Nyinondi

Department of Language Studies, College of Social Sciences and Humanities

Sokoine University of Agriculture, Morogoro, Tanzania

Received: June 4, 2016 Accepted: July 4, 2016 Published: July 8, 2016

doi:10.5296/ijele.v4i2.9711 URL: http://dx.doi.org/10.5296/ijele.v4i2.9711

\begin{abstract}
Teaching large classes interactively has always been posing great challenges to language teachers in many of the developing countries. This study sought to explore whether the blending of WhatsApp Social Networking Tool (WSNT) in English Second Language (L2) learning class would make the class more interactive. Specifically, the study investigated roles and extent to which WSNT helps in the improvement of English Proficiency. Further, it explored advantages and challenges of using the tool in L2 learning. The study was conducted at one university involving first year undergraduate students who were pursuing different programs, and English grammar course was a compulsory course to them. WSNT was blended in grammar course for a period of one semester. Thereafter, evaluation forms and WhatsApp discussion board were used in data collection. It was realised that the tool plays a great role to the largest extent in helping students learn English interactively and
\end{abstract}


collaboratively. In respect to advantages and challenges, it was reflected that the benefits of blending WSNT in L2 classroom far outweigh the challenges. This implies that WSNT does much good than harm on student's L2 learning and development. The study concludes that WSNT can be fully utilised for education purposes. The government is therefore urged to provide loans to university students for online mobile learning tools as part of their special faculty requirements. Also, instructors are recommended to adapt the tool synchronously in their courses because the tool is effective at creating interactive learning environment.

Keywords: WhatsApp, Second Language, Large Classes, Potentials, Opportunities

\section{Introduction}

\subsection{Background}

Teaching English as a second or Foreign Language (FL) has been a very challenging activity in the field of Applied Linguistics. Up to the moment, various Second Language (L2) teaching and learning theories, approaches and methodology have been proposed and implemented in language classrooms. Since the implementation of these approaches and methodology requires skilled human resources and efficient physical resources (i.e. conducive language teaching and learning environments, learning materials and the use of technology), developing nations have been struggling to meet the teaching standard for ages. This has made the process of acquiring English as a L2 or FL very challenging, if not difficult (See Brock-Utne, Desai \& Qorro, 2003, 2005, Rubagumya, 1990; Rugemalira, 1990). Gass and Mackey (2007) define the terms second language, acquisition and learning as:

(1) Learning in both second and foreign language environments, (2) learning in both classroom and naturalistic settings and (3) learning a second language as well as learning a third, fourth language, and so on. ... acquisition and learning are used interchangeably, meaning only that non-primary language acquisition is the focus. (p. 1).

It is obvious that L2 teaching and learning need a lot of investment in terms of human and physical resources. However, in Tanzania these important aspects of L2/FL language teaching and learning are yet to be fully achieved due to meager resources. As a result, English language teaching and learning is still a goose chasing game. For instance, the majority of instructors are still mainly using teacher-centered approach (Kitta \& Tilya, 2010; Vuzo, 2010), which is not efficient in L2 teaching. Also, it is the teaching of large classes which are unmanageable for interactive learning. To overcome these challenge, the Sokoine University of Agriculture (SUA) has just revised its curricula and come up with groundbreaking teaching approaches, Communicative Language Teaching (CLT) being a dominant approach. Since CLT insists on learning by doing (See Richards, 2006; Brown 2015), it has been a bit difficult to implement it due to some challenges. For example, the ratio of teacher/ instructor to students is too high (1:250-300). Further, the nature of the classrooms does not encourage community learning environments as the chairs and the desks are not movable. The majority of Tanzanian students do not talk in public as a result of culture and student centred approach. 
These factors, among others, undermine the process of teaching and learning English and related courses. Apart from adjusting their teaching styles to overcome these challenges, instructors have also opted to integrate modern technology in order to complement classroom teaching.

One of the technological tools that has been so influential among the instructors and their students is WhatsApp. However, little is known regarding this social networking site in teaching and learning. For example, Barhoumi(2015) studied the effectiveness of using mobile technologies to support the learning of a course entitled Scientific Research Methods in Information Science. Ishengoma and Mtaho (2014) examined to what extent are the Local Online Social Networking sites (LOSNs) in Tanzania are exploited as e-learning platforms. Their findings showed that LOSNs are not fully utilized as e-learning tool, but are used mainly for providing educational news compared to other educational aspects such as provision of study materials and educational advice. Also, Bouhnik and Deshen(2014) conducted an exploratory research on the use of WhatsApp on classroom communication. On the contrary, Army (2014) explored the impact of using WhatsApp mobile learning activities on the achievement and attitudes of female students using mobile devices at the university. Based on the reviewed literature (See Ishengoma \& Mtaho, 2014; Army, 2014; Bouhnik \& Deshen, 2014; Barhoumi, 2015), the use of WhatsApp in teaching and learning in many of the countries is at its infant stages. With a special reference to WhatsApp use in L2 learning in many of the developing countries like Tanzania, studies have never been done, possibly because WhatsApp tool is a recent inversion (Barhoumi, 2015).

\subsection{Problem Statement}

Teaching large classes interactively has really been posing great challenges to language teachers in the country. As observed by Kitta and Tilya (2010) and Vuzo (2010) much of the teaching and learning in the country is largely teacher centred mainly because teachers teach large classes. Although teachers try their best to manage classes interactively through, among others, group works, discussions and presentations, the interaction during the teaching and learning processes, still is never fully achieved because few students get opportunities to participate. In this regard, instructors try to adapt different strategies such as using social networking sites to blend their English or Communication Skills (SC) teaching for their classes to be much more interactive. This study, therefore, targeted at exploring whether the blending of WhatsApp Social Networking Tool (WSNT) in L2 large class would make the class more interactive. Specifically, the study aimed at:

Investigating the roles of WSNT when is used to supplement L2 classroom interaction in universities.

- Exploring the extent to which WSNT helps in the improvement of English Language Proficiency (ELP).

- Identifying the advantages and challenges of using WhatsApp for L2 learning in higher education in Tanzania 


\section{Literature Review}

\subsection{Application of Technology in Teaching and Learning}

The use of modern technologies has changed the way educationists view teaching and learning processes. As pointed out by Dehghanpour and Hashemian (2015), technologies help teachers to apply new ways (e.g use of audio- visual aids such as video, radio, TV, computers, mobile phones etc.) of teaching and learning. Also, technology offers a number of electronic tools in and outside the classroom (Slaouti, Onat-Stelma, and Motteram, 2013) that can help in the teaching and learning processes. For example, Prensky (2001) observes that the today's students are technologically based generation who spend most of their time using technological tools such as computers, video cams, cellular phones, among others. Further, Altun (2015) and Brozek and Duckworth (2015) add that English language learners benefit from a technology based language teaching and learning, since technology has made learning effective. Adding on the essence of technology in education, Lacina (2004), Edmodo (2010), Saxena (2013), Altun (2015), and Dehghanpour and Hashemian, (2015) enumerate a number of benefits that technology can bring about: (1) teachers can share their experiences related to teaching and learning online; (2) it encourages independent learning on the part of students; (3) it enhances students- teacher interaction that saves time and space. It is, therefore, worth mentioning here that integrating this new technology in the teaching and learning brings the need for thoroughly thinking on the type of technology and the influence on students' development.

\subsection{WhatsApp Tool}

Slaouti, Onat-Stelma, and Motteram (2013) maintain that WhatsApp, Skype and GO SMS Pro are the commonly used social network applications among students in learning in many of the developed nations. In developing nations such as Tanzania, WhatsApp, Facebook and Instagram are very common among students, Whats App being the leading. However, the use of these tools, to a large extent, is not in learning. WhatsApp tool is a mobile messaging app which allows people to exchange messages (See its icon in Fig.1). The app according Barhoumi (2015) was created in 2009, and 'WhatsApp comes from an English phrase 'what is up' meaning that what's new' (222). Through WhatsApp, users can create groups, send each other images, video and audio clips. While Mwakapina(2016) asserts that any language is best learnt when there are enough rooms for interaction/ dialogue, most of the English/ SC classes, at SUA, are characterised by large class sizes (See Fig.2), which limit interactive learning to the extent that supplementing these classes with an online mobile tool becomes inevitable. Thus, there is a need of trying this technology in our classrooms. 


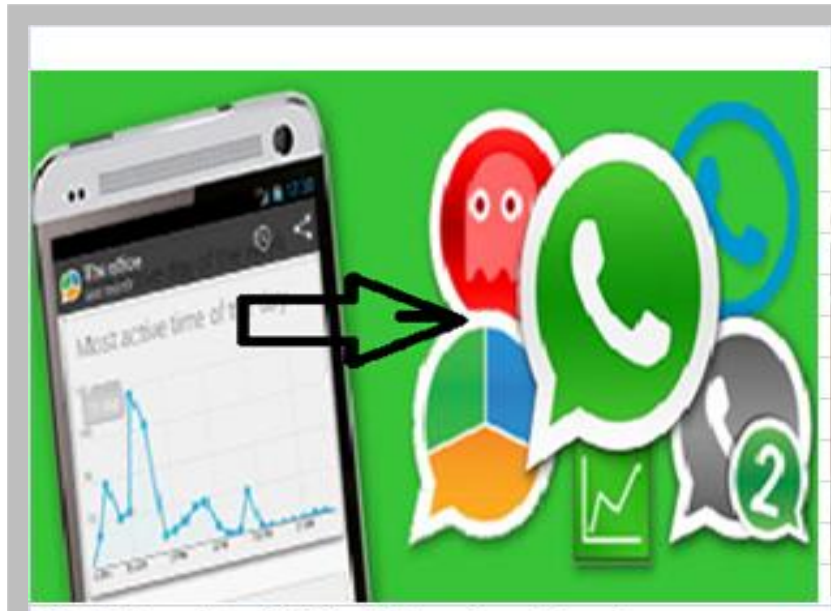

Fig1: Sample of WhatsApp Icon Used

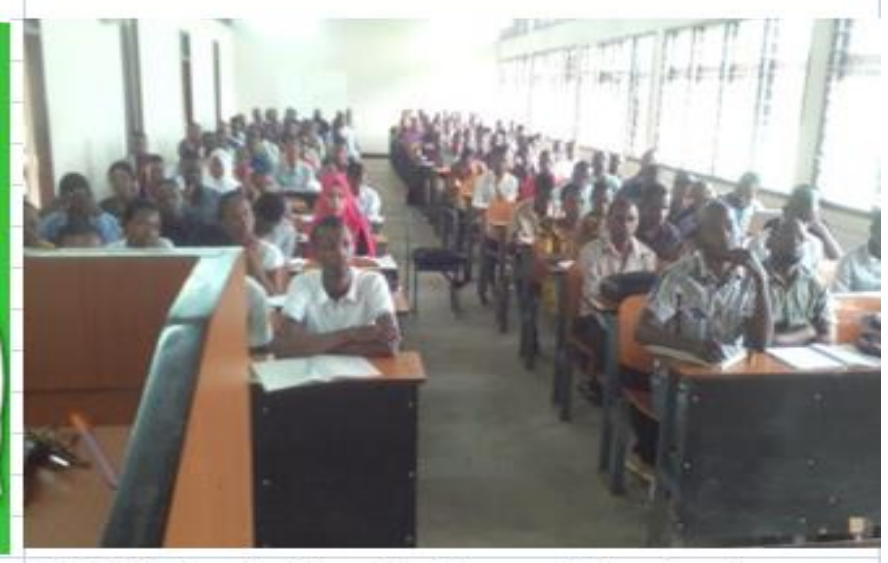

Fig.2: Students Attending Normal Class Sessions

\subsection{Challenges for Implementing Technologies by Universities in Developing Countries}

One of the challenges is the fact that majority of actors view ICT as an integral part of health, administration and small business perse (Osterwalder, n.d). They forget the fact that ICT cuts across all sectors. As a result, this misconception has brought drawbacks on the use of ICT in educational sector of the developing countries like Tanzania. World Bank (2002) insists to integrate the technology in other sectors especially in education, finance, and public sector.

The next challenge is the financial constraints. Many public universities have been constrained with financial resources due to budget cuts from the government (Devarajana, Mongab, \& Zongo, 2012; Kavuma, 2011; Macuacua, 2008). These financial constraints in universities have led to ICT being not prioritized. Since investment in ICT requires financial resource, majority of universities cannot afford buying cutting edge technologies, internet access and other technologically related materials for teaching and learning. Up to the moment, many universities lack the important components such as virtual labs and other electronic equipment. However, some universities are striving to integrate ICT in the teaching and learning. For instance, SUA is in the final stage of installing fibre optic cables across the university, and through the Innovative Agricultural Research Initiative (iAGRI) is in the move of establishing a Language Resource Centre which will run a virtual lab. Generally, lack of fund has multiplicities of effects on the use of ICT.

Lack of trained staff to run ICT courses or technological equipment is not surprising. As you may recall, universities lack financial resource, and also, the field is still at infant stage. Additionally, many universities in the country seem to lack policy that guide the use of technology in the teaching and learning process. Despite of the aforementioned challenges, language instructors at SUA are trying to incorporate Smartphone in their teaching so that they could come up with recommendations for better utilization of the available technology.

The current study therefore sought to investigate into the opportunities, potentials provided by WSNT, and its challenges when is used to supplement L2 classroom interaction in universities. Specifically, the study sought to answer the following questions: first, what are the advantages and challenges of using WhatsApp in L2 learning in higher education? Secondly, to what extent WSNT helps in the improvement of English language proficiency? 
And, what are the roles of WSNT when is blended in L2 learning classroom?

\section{Methods}

\subsection{Area of the Study and Participants}

The data for the study were collected from first year students who were studying English grammar course at Sokoine University of Agriculture (SUA). The course is a remedial for all first year students at the university who exhibit limited English Language Proficiency (ELP) after doing the university screening test. A total of 142 students were selected to form a sample of the study. However, during evaluation day through evaluation form 120 students were available and participated in the evaluation of the teaching and learning process after WhatsApp being blended in the learning for a semester. Within the 120 participants, majority, 90.8 percent constituted the youth aged between 17- 25 years, and the remaining 9.2 percent were the participants of different age ranges from 26 - 52. On the contrary, within the 90.8 percent of youth of 17-25 years, majority 81.6 percent were science education students, with different specialization, while 9.2percent were pursuing Bachelor of Science in Informatics.

Table 1. Cross tabulation of Age and Degree Programs of Participants

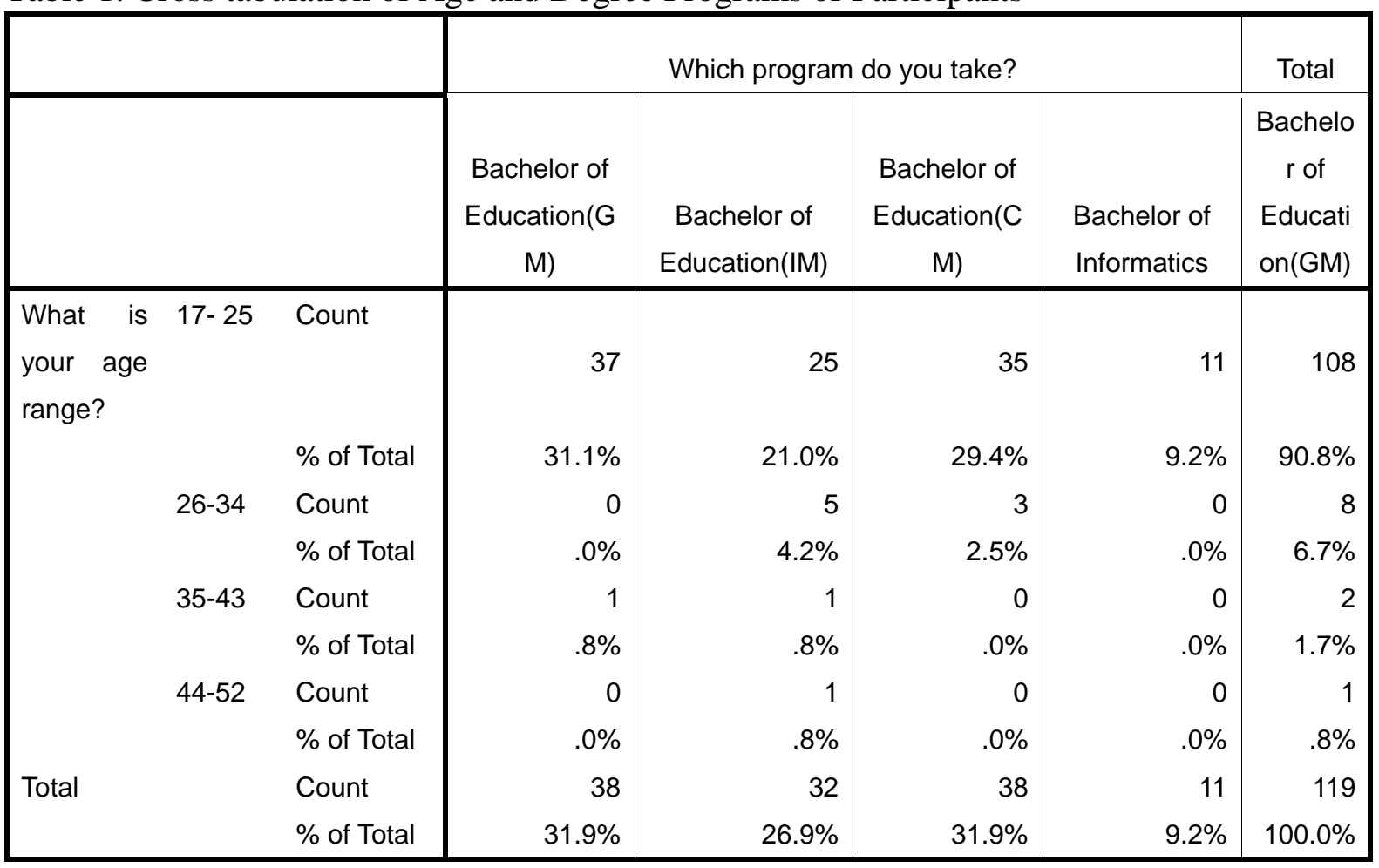

\subsection{Sample and Sampling Procedure}

The selection of the classes to be involved in WhatsApp mobile learning was done randomly. There were several classes with different degree programs taught by different instructors. A class with four degree programs namely: Bsc. Education Geography Mathematics (GM), Chemistry Mathematics (CM), Informatics Mathematics (IM) and Bsc. Informatics taught by 
one of the researcher was involved. A purposive sampling was used in the selection of participants. All the students were purposively selected mainly depending on the fact that they were all doing remedial English grammar course, and secondly, all were in possession of Smartphone with WhatsApp application installed. Therefore, an instructor who was assigned to teach this class formed the WhatsApp group and became the administrator (Admin) and moderator of the group and other two instructors, who are also researchers in the study, were added to moderate student's posts and provoke student's participations.

The first two weeks of November, 2015 at the beginning of semester were weeks for registration in the WhatsApp group. The students participated to learn English grammar course synchronously through both normal classroom sessions and WSNT. The grammar course has five topics: the Basic Sentence Structure and Punctuation Skills, the Sentence Logic and Clarity, Articles and Nouns, Tense System (Verb phrase), Transitional Markers and Paragraph Crafting .The activities and discussions in WSNT forum were done weekly. Therefore, the discussion topics and online links for two short readings were posted on each Monday at 00:01 in the morning, and the due date in each week was Sunday at 23:59pm.

\subsubsection{Ethical Consideration}

This study followed the standard procedures for social research, whereby permission was granted by the relevant institution. All participants in the study willingly agreed to participate and confidentiality of the participants was strictly observed.

\subsubsection{Instruments}

There were two tools that were used in data collection. Evaluation forms were administered after students have participated in learning English course through normal class sessions and through WhatsApp tool to evaluate the role of WSNT in L2 learning. Likert scale or rating scale on the evaluation forms was used to rate responses of participants on the opportunities provided by WSNT on English L2 Learning. For example, students were to rate with responses like 'I agree, I disagree and I don't know', on the statement which says 'Using WSNT in Supplementing English Classroom Learning Helped me a lot to Learn English. The second method was the WhatsApp discussion forum or participation in the forum, where students posted their video, answers to short quizzes and instant responses to various colleagues' queries, etc (See Fig. $3 \& 4$ ).

\subsubsection{Study Design and Data Analysis Methods}

The study followed a case study and exploratory research designs where data were collected from a sample of respondents from a defined population as explained above. The data were analyzed using mainly quantitative data analysis methods as data SPSS and Excel were used. Also, qualitative methods were used to judge the interaction patterns. Finally, the findings were presented addressing specific research questions. 


\section{Findings and Discussion}

\subsection{Opportunities (Roles) Provided by WSNT in English L2 Learning}

In this aspect, the data were collected to explore the strength of using WhatsApp tool in L2 learning. When asked to indicate whether the application has a positive role for improving their English proficiency, majority (Table 2) of students indicated positive feelings that WSNT has positive roles in helping them to learn English, only 18. 4 percent of students indicated that it did not help them.

Table 2. Role of WSNT in L2 Learning

\begin{tabular}{|l|l|l|l|l|l|}
\hline \multicolumn{2}{|c|}{} & Frequency & Percent & Valid Percent & Cumulative Percent \\
\hline Valid & I agree & 98 & 81.7 & 81.7 & 81.7 \\
\hline & I don't Know & 5 & 4.2 & 4.2 & 85.8 \\
\hline & I disagree & 17 & 14.2 & 14.2 & 100.0 \\
\hline & Total & 120 & 100.0 & 100.0 & \\
\hline
\end{tabular}

Furthermore, in investigating how WSNT helps students learn L2, the analysis went further to specific areas which students think that the tool helped them much. Table 3 indicates various items and the students' rating of responses. The table shows that students after participating in learning English through WSNT most 77.5\% agreed that WSNT helped them improve their English vocabulary, $11.7 \%$ disagreed, while $10.8 \%$ neither agreed nor disagreed on the item.

Similarly, many of the participating students $77.5 \%$ said WSNT strengthened and gave them broader understanding of the topics discussed in class by clarifying more what was discussed in class, while $17 \%$ disagreed and $8.3 \%$ of students did not know whether WSNT strengthened and gave them broader understanding of the topics discussed in class or not. Again, on the ability to ask for clarity, apology, and questions or to explain something in English language, many students $83.3 \%$ were positive that participating in English grammar course through WSNT forum helped them improve and increase their ability to ask for clarity, apology, and questions or to explain something in English.

Also, on whether WSNT could give opportunities for interactive learning which in normal classroom might not be much effective because of teaching large class sizes, the table indicates that majority of the participating students $77.5 \%$ agreed that WSNT improved their interaction than they could interact, if they would not participate in the forum. On the contrary, $19.2 \%$ were negative saying that WSNT did not help them to improve their interaction, and $3.3 \%$ did not know whether WSNT helped them improve their interactions or not.

On the same line, students were also asked whether WhatsApp helped them to identify their mistakes through editing their text and to know their errors through reading other students' texts. $91.7 \%$ were positive that WhatsApp has helped them to know their mistakes and 5.8\% 
were negative, while $1.7 \%$ of participants were neutral. Connected to this, it was the expression whether they were happy to know their mistakes/ errors and to comment on other students' text. Majority of the participating students, $92.5 \%$ agreed that they were happy to comment on other students' text and were also happy to see fellow students commenting on their own texts. Figure 3 and 4 represent samples of discussions in the forum where students corrected each other's errors and mistakes.

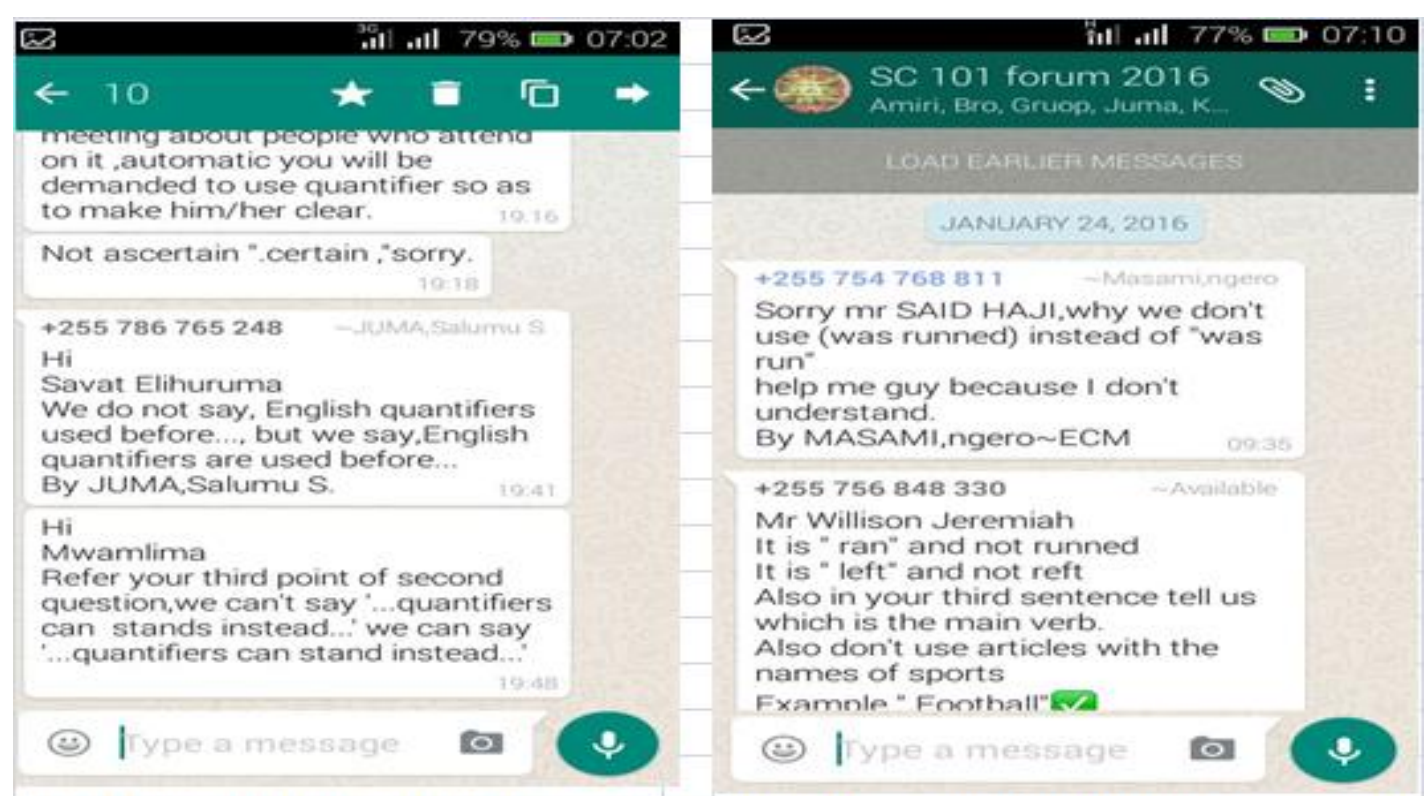

Fig.3: Forum Students' Instant Messaging / Fig.4: Forum Students' Instant Messaging B

The data from Table 3 also show that the participants did not show very positive responses on the role of WSNT on the language skills. When students were asked on whether WSNT has helped them to improve their reading and listening skills and not writing and speaking skills, $48.3 \%$ were positive and $45 \%$ were negative, and $6.7 \%$ were neutral, meaning that they don't know.

Additionally, on whether it has helped them improve only their writing and reading skills, 59.2\% were negative and $40 \%$ positive and only $0.8 \%$ were neutral. More than $59 \%$ of participants being negative, this shows that WSNT helps not only on writing and reading, but in all the Language skills, but it does much on reading and writing than in speaking and listening.

From the analysis of the language skills, the skills were rated lowly as compared to other items. It seems many students could not relate what they were doing as they write texts, listen to audio-visual clips and read some online provided readings with the improvement of the Language skills( the reading, speaking, listening and writing), possibly because this grammar course does not explicitly deal with the Language skills. 
Table 3. Table of Responses on the Role of WSNT in L2 Learning

\begin{tabular}{|c|c|c|c|c|c|}
\hline $\mathbf{S} / \mathbf{N}$ & $\begin{array}{l}\text { Expressions/Opportunities } \\
\text { provided by WSNT }\end{array}$ & I agree & $\begin{array}{l}\text { Neutral } \\
\text { (I don't } \\
\text { know) }\end{array}$ & I disagree & $\begin{array}{l}\text { Total } \\
\text { frequency } \\
(\text { Total \%) }\end{array}$ \\
\hline 1 & $\begin{array}{l}\text { WhatsApp has Helped me to } \\
\text { improve my English Language } \\
\text { Vocabulary }\end{array}$ & $93(77.5 \%)$ & $13(10.8 \%)$ & $14(11.7 \%)$ & $120(100 \%)$ \\
\hline 2 & $\begin{array}{l}\text { WhatsApp strengthened and gave } \\
\text { me broader understanding of topics } \\
\text { discussed in class }\end{array}$ & $93(77.5 \%)$ & $10(8.3 \%)$ & $17(14.2 \%$ & $120(100 \%)$ \\
\hline 3 & $\begin{array}{l}\text { It has increased my ability to ask for } \\
\text { clarity, apology, questions or to } \\
\text { explain something in English }\end{array}$ & $100(83.3 \%)$ & $6(5.0 \%)$ & $14(11.7 \%)$ & $120(100 \%)$ \\
\hline 4 & $\begin{array}{l}\text { It has helped me to improve my } \\
\text { reading and listening skills not } \\
\text { writing and speaking }\end{array}$ & $58(48.3 \%)$ & $8(6.7 \%)$ & $54(45.0 \%)$ & $120(100 \%)$ \\
\hline 5 & $\begin{array}{l}\text { It has helped me improve my } \\
\text { writing and reading skills and not } \\
\text { speaking and listening }\end{array}$ & $72(60.0 \%)$ & $4(3.3 \%)$ & $44(36.7 \%)$ & $120(100 \%)$ \\
\hline 6 & $\begin{array}{l}\text { It has helped me improve only my } \\
\text { writing skills and reading only }\end{array}$ & $48(40.0 \%)$ & $1(0.8 \%)$ & $71(59.2 \%)$ & $120(100 \%)$ \\
\hline 7 & $\begin{array}{l}\text { Participating in the English forum } \\
\text { helped me improve my interaction } \\
\text { in English than when I wouldn't } \\
\text { participate }\end{array}$ & $93(77.5)$ & $4(3.3 \%)$ & $23(19.2 \%)$ & $120(100 \%)$ \\
\hline 8 & $\begin{array}{l}\text { WhatsApp helped me to know my } \\
\text { errors and mistakes through editing } \\
\text { and errors/mistakes of other } \\
\text { students }\end{array}$ & $110(91.7 \%)$ & $2(1.7 \%)$ & $7(5.8 \%)$ & $119(99.2 \%)$ \\
\hline 9 & $\begin{array}{l}\text { WhatsApp helped me to know } \\
\text { topics of the next lesson/ What is } \\
\text { going to be done in the next lesson }\end{array}$ & $89(74.2)$ & $8(6.7 \%)$ & $23(19.2 \%)$ & $120(100 \%)$ \\
\hline 10 & $\begin{array}{l}\text { I was happy to know my } \\
\text { mistakes/errors and to comment on } \\
\text { peers' texts/peers' errors }\end{array}$ & $111(92.5 \%)$ & $3(2.5 \%)$ & $6(5.0 \%)$ & $120(100 \%)$ \\
\hline
\end{tabular}


4.2 To what Extent WSNT Helps Students on Grammatical Items?

The second objective of the study was to determine the extent to which WSNT helps in the improvement of English Language Proficiency (ELP). The overall results on this aspect indicate that WSNT helped to improve ELP of the majority, 87.5 percent of the participants' rated to a large extent and very large extent (Table $4 \&$ Chart), while it was only few percentage, 12.5 of those who indicated that it has helped them improve their ELP to a small extent and very small extent.

\section{Extent of Improvement of ELP due to WSNT}

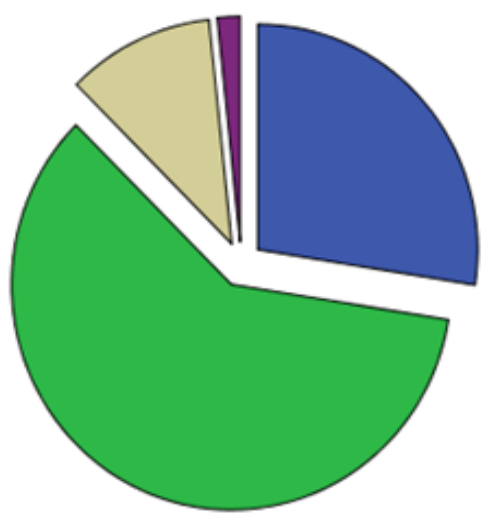

To what extent has the forum helped you
improve on the components of English grammar(English Proficiency)

$\square$ To a Very Large extent

To a Large extent

To a Small Extent

To a Very Small

One of the goals of English course at SUA is to help students improve English grammar. This study narrowed down to grammatical aspects that students are required to improve on. The findings from both the WhatsApp forum discussion and the evaluation forms indicate that WSNT helps students to improve in writing correct English sentences. For example, as presented in Table4, majority of the participants indicated that WSNT helped them to improve the writing of the sentences to a large extent.

Similarly, on modal auxiliary verbs, linking sentence in a paragraph, participants indicated that WhatsApp helped them to a large extent to improve on those aspects. For example, on modal auxiliary verbs participants, 85 percent confirmed that the tool helped them to interpret the meaning of modal auxiliary verbs. It was only 15 percent who indicated that the tool helped them to a small extent. Additionally, on English terminologies many students (Also See Table 4) were of the opinion that WSNT has helped them to a large extent.

Despite the fact that majority of the participants, 89.1 percent indicated in the evaluation form that WSNT helped them to a large extent improve the interpretation of the meaning of various word orders (active, passive, question formation, etc), which is confirmed to be true from the discussion forum/ board. The observation from the forum discussions however indicates that 
majority of the students were still challenged with some word orders. For example, some of the students used wh-fronting in questions formation( Wh-fronting is when Wh is put at the end of the question), while many in most cases formed questions that lacked a question marker or formed questions using $W h$, but without inversion of a helping verb and a subject (See Fig.4).

Table 4. Extent of the Improvement of ELP due to WSNT

\begin{tabular}{|c|c|c|c|c|c|c|}
\hline \multicolumn{7}{|c|}{$\begin{array}{l}\text { To what extent has the forum helped you improve on the components of English } \\
\text { grammar(English Proficiency) }\end{array}$} \\
\hline \multicolumn{2}{|r|}{ Expressions /Statements } & $\begin{array}{l}\text { Very } \\
\text { Large } \\
\text { Extent }\end{array}$ & $\begin{array}{l}\text { Large } \\
\text { extent }\end{array}$ & $\begin{array}{l}\text { Small } \\
\text { extent }\end{array}$ & $\begin{array}{l}\text { Very } \\
\text { Small } \\
\text { extent }\end{array}$ & $\begin{array}{l}\text { Total } \\
\text { Frequency } \\
\text { (Total \%) }\end{array}$ \\
\hline 1 & $\begin{array}{l}\text { To what extent WSNT has } \\
\text { helped me improve on } \\
\text { ELP? }\end{array}$ & $33(27.5 \%)$ & $72(60 \%)$ & $13(10.8 \%)$ & $2(1.7 \%)$ & $120(100 \%)$ \\
\hline 2 & $\begin{array}{l}\text { It has helped me to create } \\
\text { English sentences } \\
\text { accurately }\end{array}$ & $44(36.7 \%)$ & $63(52.5 \%)$ & $12(10.0 \%)$ & $1(0.8 \%)$ & $120(100 \%)$ \\
\hline 3 & $\begin{array}{l}\text { It has helped me interpret } \\
\text { the meaning of modal } \\
\text { auxiliaries }\end{array}$ & $40(33.3 \%)$ & $62(51.7 \%)$ & $15(12.5 \%)$ & $3(2.5 \%)$ & $120(100 \%)$ \\
\hline 4 & $\begin{array}{l}\text { It has helped me to link } \\
\text { sentences and paragraphs } \\
\text { clearly and logically }\end{array}$ & $60(50.0 \%)$ & $47(39.2 \%)$ & $12(10.0 \%)$ & $1(0.8 \%)$ & $120(100 \%)$ \\
\hline 5 & $\begin{array}{l}\text { It has helped me learn new } \\
\text { English terminologies/ } \\
\text { vocabulary }\end{array}$ & $58(48.3 \%)$ & $48(40.0 \%)$ & $12(10.0 \%)$ & $2(1.7 \%)$ & $120(100 \%)$ \\
\hline 6 & $\begin{array}{l}\text { It has help me interpret the } \\
\text { meaning of various words } \\
\text { orders(active, passive, } \\
\text { questions formation, etc }\end{array}$ & $67(55.8 \%)$ & $40(33.3 \%)$ & $9(7.5 \%)$ & $4(3.3 \%)$ & $120(100 \%)$ \\
\hline 7 & $\begin{array}{l}\text { It has helped me to be } \\
\text { interactive and } \\
\text { cooperative in my text }\end{array}$ & $52(43.3 \%)$ & $49(40.8 \%)$ & $12(10.0 \%)$ & $7(5.8 \%)$ & $120(100 \%)$ \\
\hline
\end{tabular}


By and large, the results on Table 3 indicate that majority of participants agreed positively that supplementing normal English L2 classroom with WSNT has a positive role of helping learners improve English language learning. This finding concurs with what was realised by Army (2014) that mobile learning based on WhatsApp social networking has a high positive impact on the achievement test of students.

Based on each individual grammatical item, it has been realised that on each individual grammatical item more than 75 percent of participants agreed that WSNT has helped them by providing enough opportunities to improve English vocabulary, giving broader understanding of the topics discussed in class, improving English language interactions, giving priorinformation of what will be discussed in class/ in a next lesson, giving opportunities for students to know their errors and mistakes in their texts and an opportunity for self and peer assessment. This finding is in line with Pence (2007)'s comment that educational mobile tools have emerged and show great potential to help students construct and share information and knowledge for learning.

Generally, on the extent of English improvement when WSNT is blended in the teaching and learning, the overall findings indicate that majority of the students were positive that blending English large classes with WSNT helped them improve English proficiency to a large extent. These findings are in alignment with Altun (2015) and Brozek and Duckworth (2015) that English language learners benefit much from technologically based teaching and learning contexts.

\subsection{Perceived Advantages and Challenges of WSNT in the Teaching and Learning}

The study also aimed at exploring what students considered to be the advantages and challenges of using WhatsApp in teaching and learning process. After participating in learning L2 using WSNT several advantages and challenges were highlighted (See Table5). However, it was observed that the use of WSNT in teaching and learning has more advantages than challenges. Some of these advantages and challenges are described hereby:

To begin with the advantages, WSNT provides equal chances or opportunities for participation. Unlike in normal classrooms whereby few students can be given opportunities to participate in discussions, because of limited time and high class size, a class blended with WSNT offers equal and fair opportunities for students to participate in the forum at their own convenient times. What matters is for them to meet the set deadlines. For that case, many students participate in the learning process. As a result, they benefit from the learning process.

Next, it saves time and broadens the coverage. Many students can participate at the same time. Again, many things or topics can be covered at a time. Not all students are required to participate at once in a given time. Likewise, aspects not well covered in class can be discussed through WSNT. Therefore, time is saved and coverage broadened because each student can participate at his/her own free convenient time, and aspects not covered in class are covered outside the classroom through WSNT.

Also, it enhances cooperation and collaboration between students-students or students - the teacher/instructor. Students learn language beyond the classroom limits. Hence, students get 
opportunities of extending classroom discussion in many areas like outside their classroom i.e at home, hostel, bus stop etc. This merit is support by what was realised by Barhoumi(2015) that the tool facilitates online discussions and collaboration from school to home in a blended mobile lecture. Therefore, blending normal classroom learning with WSNT gives students opportunities to discuss outside the classroom different topics related to the course taught face-to-face.

Equally, WSNT does not need face to face interactions. Unlike many classroom language learning contexts, which need the teacher to be physically, blending WhatsApp tool with a normal classroom L2 learning is not necessary for a teacher to be there or to be active and alert all the time when students post their ideas. This is to say, students get to learn from each other. Hence learning takes place outside the class where the teacher is not there.

Furthermore, with WSNT, it is possible for an instructor to be consulted at any time. Instructors in universities have tight schedules. For our cases, Tuesday and Friday 14hrs to 16hrs weekly were the only hours set for consultations. Four hours only in a week for consultation for more than 200 students are not enough. Through involving WSNT, it has been realised that an an time students can consult the teacher for anything discussed in class. Therefore, WSNT makes the instructor or the teacher easily accessible and available at any time.

Similarly, always self and peer assessment have been challenging in our ESL large classes. WSNT has been observed to be effective in the enhancement of students' assessment of peers' posts. Though, it was impossible to practice anonymous peer assessment. For example, students were only able to correct errors and mistakes they saw on colleagues' text or on recorded videos as they were participating (See Fig3\&4). There was no automated way of sharing rubrics and swapping posts to let students assess peers' posts unanimously. Generally, irrespective of lack of anonymity, peer review or peer learning and assessment are well enhanced using WhatsApp tool.

The tool also creates a safe and supportive environment for learning. Students are always worried of making mistakes as they learn, but WhatsApp makes them feel relaxed among friends. When students feel relaxed and safe among friends their tension decreases. For that case, they are much likely to participate more and learn more.

Apart from the tool playing an important role in language learning, it does not go without challenges. First, students can remove themselves from the group at any time. There is no way of retaining students from leaving the group, once they have joined. For example, after few weeks of participation in the WSNT, some students started to leave the group. After the instructors noticing that there is a tremendous dropout, they came up with motivational strategies to make students stay in the group. One of the strategies was to give bonus/scores for those who participated fully in the forum. On hearing about this strategy, many students who had left the group asked to be re-added. Hence, the freedom to leave the group at any time hinders the achievement of the intended objectives of involving WSNT in the learning of any course. 


\section{MlMacrothink}

International Journal of English Language Education

ISSN 2325-0887

2016, Vol. 4, No. 2

The next challenge is, there is no way of blocking students' posts posted after the deadlines. For example, in this class, students were to participate on weekly bases. In each week, they were to read two short online articles and after reading they had to do quizzes and comment on anything that the instructors found worthy commenting. Although, the weekly discussions begun from Monday 00:01 am and ended Sunday 23:59:59pm, some students posted after the deadline on Monday or Tuesday, and there were no ways of blocking their post. As a result, this interrupted the flow of the new topic.

It was again observed that WSNT doesn't give opportunities to save your post and continue later when you have time. Due to this, the instructors need enough time to go through each student's posts. Many students despite of being told, when they post their ideas, they should make sure they post or answer all the questions in one post for easy evaluation, many kept on attempting one part of the question today and the other part of the same question attempted two days after. As a result, instructors spent a lot of time searching through manually all posts of an individual student and evaluate them. For that case, evaluation exercise turned out unrealistic and laborious because the tool does not provide ways of sorting all posts of an individual together.

Additionally, many students pointed out that internet connection was a challenge to them. All students relied on the subscription to the internet provided by their mobile operators (Tigo, Vodacom, Airtel, etc). However, most complained that the subscription fee was too high for them to buy enough internet bundles that could last for a week or month. As result, they opted for cheaper internet bundles which could help them subscribe for a day by participating in the forum and then disconnecting the data after participation.

Sending of indecent pictures and messages was the other challenge observed. Some participants were sending indecent pictures and messages. Because working with students is working with people with different behaviors, personalities and moods, despite of restricting them to send indecent pictures and messages through terms and conditions of participating in the forum, still some appeared to send indecent pictures and messages. Even after being removed from the group many kept on asking for forgiveness by saying that the pictures or the sent messages were intended for the other group.

Moreover, WSNT in education in Tanzania is challenged by overloaded curricula. Most of the curricula in our universities are parked with a lot of courses. For example, at SUA, a student pursuing a Bachelor of Science in Education might have 10 courses in one semester, and the10 courses have fixed hours for lectures, independent study, practical training, seminars/tutorials, etc. Besides, some practical training are fixed even on Saturdays and Sundays. As a result, students can have limited time to participate in the forum. As observed in this study, many were participating when it is closer to the set deadline.

\subsection{Pedagogical Steps in Applying WhatsApp Tool to Support Classroom Learning}

After involving WhatsApp tool in the learning of English course, it was realised that WhatsApp works effectively, if the instructor will follow the suggested 6 steps in the process of adapting and using the tool: 
i. Introduce WSNT to the Students

You need to inform the students; why it is important to blend the given course with WhatsApp tool. Normally, when students know the goal of adapting it will tend to be cooperative. Therefore, take time to clarify about the tool and the expected behaviors from the students as they participate in the technologically blended learning.

\section{ii. Involve Students in the Creation of Terms and Conditions}

Students should be involved to create terms and conditions of participation in the platform. When they are involved, they will feel to own the learning. If students come up with the dos and don'ts by themselves they are more likely to follow them. For that matter, making sure everyone knows the terms and conditions of participation can reduce disruptive behaviors as the learning process progress.

\section{iii. Devise Motivational Mechanisms for Participants}

Apart from telling them the importance of participation in the forum/platform, students will participate more, if they will know, there is a reward given on participation. For example, in this study, in the first two weeks of participation, few students willingly had joined the forum when the instructors introduced WhatsApp forum to them. It is until when the instructors informed them that activities from the forum contribute 15marks of continues assessment, more and more students demanded to be added to the forum, even those who had left the group.

iv. Create and Add Members in the Group

After going through stage one to three, you will need now to add students/members in the forum.

\section{v. Share Students' Thread/ Discussion Posts through your Email to Ease Assessment}

In a context where the WhatsApp group has more than 120 participants, assessing students' posts by reading them using a phone may turn out to be unrealistic. This is because of the inconveniences caused by phone's screen size which in most cases is small. The convenient and easy way is to send students' posts via email for print outs.

\section{vi. Communicate the Forum Feedback Back to Students}

The feedback of weekly forum discussions could be communicated to students through the same forum or sometimes through a normal classroom session. 
Table 5. Perceived Challenges and Advantages of Using WSNT in L2 Learning

\begin{tabular}{|c|c|}
\hline $\begin{array}{c}\text { Perceived Advantages of WSNT in L2 } \\
\text { learning }\end{array}$ & $\begin{array}{l}\text { Perceived Challenges of WSNT in } \\
\text { L2 learning }\end{array}$ \\
\hline $\begin{array}{l}\text { 1) Gives equal opportunities of participation } \\
\text { 2) It saves time } \\
\text { 3) It does not need face-face interactions } \\
\text { 4) It broadens coverage } \\
\text { 5) Gives opportunities for student's self } \\
\text { assessment and peer assessment } \\
\text { 6) Students learn by doing } \\
\text { 7) Students become active and alert to follow } \\
\text { what is taught in class } \\
\text { 8) It strengthens familiarization, cooperation } \\
\text { and interaction } \\
\text { 9) Shy students participate effectively } \\
\text { 10) Helps in sharing knowledge, skills and } \\
\text { information instantly } \\
\text { 11) Students become independent learners } \\
\text { 12) It is possible to exchange ideas, pictures, } \\
\text { information, videos, audio clips, texts, etc. } \\
\text { 13) Increases confidence and widens } \\
\text { understanding on things discussed in class } \\
\text { 14) Helps students to use their mobile phone in } \\
\text { education effectively } \\
\text { 15) It forces students to think critically through } \\
\text { analysing other students ideas } \\
\text { 16) At any time students can consult the } \\
\text { teacher for anything discussed in class. } \\
\text { 17) Students automatically improve the } \\
\text { language skills as they participate in } \\
\text { reading articles, watching video, writing } \\
\text { 18) Create a safe and supportive environment } \\
\text { for learning }\end{array}$ & $\begin{array}{l}\text { 1) It is costly-(the equipment and } \\
\text { airtime bundles) } \\
\text { 2) Posting of indecent pictures } \\
\text { and messages } \\
\text { 3) it is not easy for the instructor to } \\
\text { evaluate every student's posts } \\
\text { through phone } \\
\text { 4) Unrelated posts or questions } \\
\text { from previous topic in } \\
\text { discussion make discussions to } \\
\text { go off course } \\
\text { 5) Limited knowledge on using } \\
\text { Smartphone or tablets } \\
\text { 6) There are no ways of blocking } \\
\text { posts posted after the due date } \\
\text { 7) Students once joined can leave } \\
\text { the group at anytime. } \\
\text { 8) No mechanism of sorting posts } \\
\text { of an individual student together } \\
\text { 9) Overloaded curricula. }\end{array}$ \\
\hline
\end{tabular}




\section{Conclusion and Recommendations}

This study had three objectives to address. First, to investigate into the opportunities (roles) provided by WSNT in supplementing L2 classroom interactions in universities. Next, was to determine the advantages and challenges of using WSNT for L2 learning in higher education in Tanzania. Lastly, determining the extent to which WSNT helps in the improvement of English language proficiency.

The overall analysis reflected that when WSNT is blended in an L2 learning classroom plays a positive role to help students learn English language. When the analysis was narrowed deep down to specific items; participants reflected that WSNT has helped them positively by providing enough opportunities to improve English vocabulary, giving broader understanding of the topics discussed in class, improving English language interactions, giving priorinformation of what will be discussed in class, giving opportunities for students to know their errors and mistakes, an opportunity for self and peer assessment and many other.

The study concludes that WSNT plays a positive role to the largest extent in helping students learn a L2. It gives students opportunities to broaden the understanding of what was covered in class. Also, the tool enables them to interact collaboratively with each other, ask for clarity or apology, conduct self and peer assessment, and improve their general vocabulary and English related terminologies to mention a few. On the English course components, WSNT helps students to improve different grammatical components such as tense system, sentence structure and paragraph crafting, interpretation of the meaning of various word orders, and sentence clarity and logic to a large extent. In respect to advantages and challenges, challenges in developing countries like Tanzania seem to be a function of multiple factors that range from the students, lack of awareness among instructors, the curriculum, institutions in particular and the government at large. Irrespective of all these challenges, WSNT does much good than harm on students' language learning and development. Therefore, in language classes, particularly those which are large classes, instructors are urged to adapt the tool because it is evident from the study that WhatsApp is effective at creating collaborative community learning environment.

Generally, based on the conclusion, the study recommends WSNT to be blended in language teaching or in the teaching of other courses in universities by the government, institutions and individual instructors doing the following:

- First, colleges/universities are urged to provide free wireless connections within colleges/ universities premises to enable students to access internet connection through Wi-Fi.

- Secondly, mobile telephone companies also are advised to subscribe students to weekly or monthly unlimited internet packages that have been subsidized by the government.

- Also, it is advisable for the government to include online mobile learning tools as part of the special faculty requirements so that students' loans board could support by providing loans for the tools. 
- Similarly, given the currently re-emphasized paradigm shift from traditional learning to student- directed learning approaches, the government is recommended to mainstream online mobile learning through curriculum as a way to student-directed learning/ CLT.

- Likewise, instructors should facilitate students to use WSNT for educational purposes like downloading learning materials and connecting class members to WhatsApp groups where they would do interactive discussions.

- Further, instructors are urged to integrate WSNT in the English curriculum or any other courses synchronously.

\section{References}

Altun, M. (2015). The integration of technology into foreign language teaching. International Journal on New Trends in Education and their Implications, 6(1). Retrieved from www.ijonte.org

Army, A. B. (2014). The impact of whatsApp mobile social learning on the achievement and attitudes of female students compared with face to face learning in the classroom. European Scientific Journal, 10(22), 116-136.

Bouhnik, D., \& Deshen, M. (2014). WhatsApp goes to school: Mobile instant messaging between teachers and students. Journal of Information Technology Education: Research, 13. Retrieved from http://www.jite.org/documents/Vol13/JITEv13ResearchP217-231Bouhnik0601.pdf

Brock-Utne, B., Desai, Z., \& Qorro, M. (eds.). (2003). Language of instruction in Tanzania and South Africa. Dar-es-Salaam: E\&D.

Brock-Utne, B., Desai, Z. \& Qorro, M. (eds.). (2005). Language of instruction in Tanzania and South Africa. Dar-es-Salaam: E\&D.

Brown, S. (2015). Teaching listening. New York: Cambridge University Press.

Brozek, E., \& Duckworth, D. (2011). Supporting English language learners through technology. In NYSUT's Journal of Best Practices in Education. Retrieved from http://www.nysut.org/ /media/files/nysut/resources/2011/march/educators-voice-4technology /edvoiceiv_ch2.pdf?la=en

Barhoumi, C. (2015). The Effectiveness of whatsApp mobile learning activities guided by activity theory on students' knowledge management. Contemporary Educational Technology, $6(3), 221-238$.

Dehghanpour, E., \& Hashemian, M. (2015). Efficiency of using a web-based approach to teach reading strategies to Iranian EFL learners. English Language Teaching, 8(10), 11-25.

Devarajana, S., Mongab, C., \& Zongo, T. (2012). Making Higher Education Finance Work 
for Africa. Journal of African Economies, 20, 133-154.

Edmodo (2010). Edmodo: Tour (tour link). Retrieved from http:// www.edmodo.com/

Gass, S., \& Mackey, A. (2007). Data elicitation for second and foreign language research. London: Routledge.

Ishengoma. F., \& Mtaho, A. (2014). Online social network as a tool for facilitating-learning in Tanzania. International Journal of Open Information Technologies, 2(10), 29-35.

Kavuma, R. M. (2011, September, 9). In Africa's Universities, quantity threatens quality. The Guardian.

Retrieved

from

http://www.theguardian.com/global-development/poverty-matters/2011/sep/09/africa-universi ty-funding-crisis

Lacina, J. (2004). Promoting language acquisitions: Technology and English Language learners. Childhood Education, 81(2). Retrieved form http://eric.ed.gov/?id=EJ709112

Macuacua, A. (2008). The funding challenge for the African universities. Personal Collection of A. Macuacua. Eduardo Mondlane University, Maputo, Retrieved from https://www.google.com/url?sa=t\&rct=j\&q=\&esrc=s\&source=web\&cd=2\&cad=rja\&uact=8 \&ved=0ahUKEwjyzcXq6b_LAhWE1BoKHWcND60QF

Mtega, W. P., Bernard, R., Msungu, A. C., \& Sanare, R. (2012). Using mobile phones for teaching and learning purposes in higher learning institutions: The case of Sokoine University of Agriculture in Tanzania. In Proceedings and Report of the 5th UbuntuNet Alliance Annual Conference, 2012, 118-129.

Mwakapina, W. J. (2016). Grammar for successful written discourse: Are the ESL/EFL students in Tanzania universities truly learning?' International Journal of Education and Research, 4(3), 309-322.

Osterwalder, A. (n.d). ICT in developing countries: A cross-sectoral snapshot. Retrieved from http://inforge.unil.ch/aosterwa/Documents/InternetInEmergingMarkets/Publications/ISGLOB 03.pdf

Prensky, M. (2001). Digital natives, digital immigrants. On the Horizon, 9(5). Retrieved from http://www.marcprensky.com/writing/Prensky\%20\%20Digital\%20Natives,\%20Digital\%20I mmigrants\%20\%20Part1.pd

Pence, H. E. (2007). Preparing for the real web generation. Journal of Educational Technology Systems, 35(3), 347-356.

Richards, J. C. (2006). Communicative language teaching today. New York: Cambridge University Press.

Rubagumya, C. M. (1990). Language use in Tanzania. In Rubagumya, C. M. (ed), Language in education in Africa: A Tanzanian Perspective. Clevedon: Multilingual Matters.

Rugemalira, J. M. (1990). The Communication skills unit and the language problem at the 


\section{Macrothink}

University of Dar es Salaam. In Rubagumya, C. M. (ed), Language in Education in Africa: A Tanzanian Perspective. Clevedon: Multilingual Matters.

Saxena, S. (2013).Using technology in education: Does it improve anything? Retrieved from http://www.edtechreview.in/news/681-technology-in-education

Susilo, A. (2014). Exploring facebook and Whatsapp as supporting social network applications for English learning in higher education: Teaching and Learning in the 21st Century: Challenges for Lecturers and Teachers [special issue]. The Journal of Professional Development in Education. Retrieved form http://repository.widyatama.ac.id/xmlui/bitstream/handle/123456789/3317/002.\%20Adhi\%20 Susilo_Exploring\%20Facebook\%20and\%20Whatsapp\%20As\%20Supporting\%20Social\%20 Network $\% 20$

Slaouti, D., Onat-Stelma, Z. \& Motteram, G. (2013). Technology and adult language teaching. In Motteram, G (ed), Innovations in Learning Technologies for English Language Teaching. Retrieved from http://www.britishcouncil.org

Kitta, S., \& Tilya, F. (2010). The status of learner-centred learning and assessment in Tanzania in the context of the Competence- based Curriculum, Journal Papers in Education and Development of the School of Education, 29, 77-91.

Vuzo, M. (2010). Exclusion through language: A reflection on classroom discourse in Tanzania secondary schools. Journal of Papers in Education and Development, 29, 14-36.

World Bank. (2002). Information and communication technologies. A World Bank Group Strategy. Retrieved from http://www-wds.worldbank.org/external/default/WDSContentServer/WDSP/IB/2013/08/07/0 00333037_20130807130136/Rendered/PDF/800880PUB0Info00Box379796B00PUBLIC0.p df

\section{Copyright Disclaimer}

Copyright for this article is retained by the author(s), with first publication rights granted to the journal.

This is an open-access article distributed under the terms and conditions of the Creative Commons Attribution license (http://creativecommons.org/licenses/by/3.0/). 